\title{
Untraditional Methods of Growing Cucumbers on Open Areas
}

\author{
S.A. Yunusov, F.O.Bolikulov
}

\begin{abstract}
The aim of the study is to compare the parameters of the crop yields, phenological development and commercial production of cucumbers under conventional and trellis method in open areas of the Tashkent region of Uzbekistan. The technology of growing cucumbers by the trellis method in open ground for vegetables is an innovative way on small farms and in the country's gardens. Unlike the conventional method, under the trellis method the number of seedlings increases, the air exchange between plants is improved, the soil moisture content is also improved, the quality of fruits increases and the diseases in the soil decrease. In samples of Uzbekistan 740, Navruz, Sevinch, Samar F1 and Orzu F1, high merchantability in was obtained. Compared to the traditional planting method, the trellis method allowed to enhance crop yields by 4.3, 5.0, 6.6 t/ha for the Uzbekistan-740, Navruz and Sevinch varieties and increased yields by 6.5 and 6, 8 t/ha for Samar F1 and Orzu F1 hybrids, respectively. In addition, marketable products of Uzbekistan-740, Navruz and Sevinch varieties were 24.6, 32.4 and 38.8 t/ha, for Samar F1 and Orzu F1 hybrids - 39.7 and 42.8 t/ha, respectively. The research results proved the feasibility of growing cucumbers using trellis technology in open ground for similar soil and climatic conditions of Uzbekistan..
\end{abstract}

Keywords : cucumber, variety, open field, growing, trellis. .

\section{INTRODUCTION}

According to WTO forecasts, by 2050 the number of people on the planet will increase to 9.1 billion, and the soils suitable for agriculture will be reduced by 40-45 percent. Currently, one of the main priorities is to solve the problem of food deficiency, to use natural resources rationally, to create high yield crop varieties, to apply new resource-economic technology and to increase export of vegetable products. In an effective use of the land and vegetable production it is important to use new cultivation methods. In order to obtain high yield of cucumber with the best quality, the trellis method of cucumber cultivation in open fields is considered as an innovative method. This type of method can bring an effective results in the cultivation of cucumber in the plots of farms and people's gardens of the republic.

The technology of growing cucumbers by the trellis method is widely as an innovative way on small farms and in the country's gardens in many counties in the world. Unlike the conventional method, under the trellis method the number of seedlings increases, the air exchange between

Revised Manuscript Received on October 15, 2019.

* Correspondence Author

S.A. Yunusov, 1 Department of "Horticulture, melon production and potato growing" Tashkent State Agrarian University, 2, University street, Tashkent, E-mail: salohiddin.yunusov@yandex.ru.

F.O.Bolikulov, 2 Department of "Horticulture, melon production and potato growing" Tashkent State Agrarian University, 2, University street, Tashkent, E-mail: farhodbolikulov@mail.ru. plants improves, the soil moisture content improves, the quality of fruits improves and diseases in the soil decrease. The plant uses full light and solar energy. In addition, the shaping increases the full use of the deposit and the harvest, which in turn leads to an increase in yield. In the experiments in countries such as Israel, China, Korea, Hungary and Russia, it is known that the fruits of the cucumber grown by the trellis method are of good quality and the deseases are low and the yield is high $[1,2,3]$.

\section{MATERIALS AND METHODS}

Field experiments were carried out on the lands of the "Turon Ismoilova Zulfiya" farm in Kibray district of the Tashkent region. The experiments were conducted in the early periods by the trellis method and the traditional method for cucumber varieites such as Uzbekistan 740, Navruz, Orzu $F_{1}$, Samar $F_{1}$ and Sevinch. Seeds were planted in open ground on May 7 using the method of inter-row belt sowing. In the trellis method, the distance between the ribbons was 90 $\mathrm{cm}$, between the rows was $50 \mathrm{~cm}$, between the plants was 20 $\mathrm{cm}$ and feeding area of the plots was $15.4 \mathrm{~m}^{2}$. The plot consisted of 70 plants. In the traditional planting method, the planting scheme was $140+70 / 2 X 40 \mathrm{~cm}$. The feeding area of the plot was $8.4 \mathrm{~m}^{2}$. In the experiment of the traditional method, the fruits were collected 20 times and in the trellis method 23 times in a simultaneous period of cultivation during the crop season.

When the plants formed 2-3 shoots, the trellis frame was installed in the field under the experiment. As a stake the woods of poplar and willow were used, their height was 150 $\mathrm{cm}$ with $5 \mathrm{~m}$ distance between them. Over the stake the double lines of wire of $2 \mathrm{~mm}$ was tied to stake by $50 \mathrm{~cm}$ high and another side of wire was bound on the base. Each cucumber seedling was tied by its stalk with thread and pulled up to the trellis wire. So, a 1000-1100 pieces of stake, $5-6 \mathrm{kgs}$ of thread and $100 \mathrm{kgs}$ of wire with $2 \mathrm{~mm}$ were used.

\section{RESULTS AND DISCUSSION}

During the study, germination of seeds and the duration of plant growth stages were observed. Shoots of seeds were up to 10 and $75 \%$ within 4-6 days among the varieties. Early maturing varieties in 4 days $75 \%$ of the seedlings were cultivars Sevinch and Samar and Orzu $\mathrm{F}_{1}$ hybrids. However, the varieties of late maturing varieties of shoots for 6 days were Uzbekistan 740 and Novruz. The highest germination as $98 \%$ was observed for Orzu $\mathrm{F}_{1}$ hybrid and smallest germination as $85 \%$ was observed for variety Uzbekistan 740. For other varieties germination was in the range of $86-97 \%$. 


\section{Untraditional Methods of Growing Cucumbers on Open Areas}

Observations were carried out from the fruiting of the seeds to 10 and $75 \%$ of the paternal and maternal flowers. In the experiment, there was practically no difference in the appearance of maternal flowers grown in a trellis by 10 percent compared with the usual method. The blooming of $75 \%$ of the mother flowers of plants, in a trellis way was at the same time 1-2 days earlier, which is 29-31 days on samples Orzu, Samar and Sevinch. This indicator, of course, is the result of positive environmental effects on plants.
As a result of phenological observations, the first and last harvest was determined. In this case, it was discovered that the first harvest in a trellis method was earlier than usual. Samples Orzu, Samar and Sevinch are the earliest cults that gave fruit in 30-31 days, 3-4 days earlier than usual. The Navruz and Uzbekistan 740 varieties traditionally ripen within 41-45 days, and in the trellis method - 37-43 days, i.e. 2-4 days earlier than usual (table 1).

Table 1. Field germination of cucumber varieties and the duration of growth stages (2017-2018 yy).

\begin{tabular}{|c|c|c|c|c|c|c|c|c|}
\hline \multirow{3}{*}{$\begin{array}{l}\text { Variety } \\
\text { samples }\end{array}$} & 10 & $75 \%$ & \multirow{3}{*}{$\begin{array}{c}\text { Field } \\
\text { germination } \\
\text { of seeds, } \\
\%\end{array}$} & \multirow[b]{2}{*}{$10 \%$} & \multirow[b]{2}{*}{$75 \%$} & The first & Last & \multirow{3}{*}{$\begin{array}{c}\text { Fruiting period, } \\
\text { day }\end{array}$} \\
\hline & \multirow{2}{*}{\multicolumn{2}{|c|}{$\begin{array}{c}\text { the time needed } \\
\text { to shoot seeds, } \\
\text { day }\end{array}$}} & & & & \multirow{2}{*}{\multicolumn{2}{|c|}{$\begin{array}{l}\text { the time elapsed } \\
\text { before the harvest day }\end{array}$}} & \\
\hline & & & & \multicolumn{2}{|c|}{$\begin{array}{c}\text { flowering of } \\
\text { maternal } \\
\text { flowers }\end{array}$} & & & \\
\hline \multicolumn{9}{|c|}{ The usual way } \\
\hline $\begin{array}{c}\text { Uzbekistan } \\
740\end{array}$ & 5 & 6 & 85 & 35 & 40 & 45 & 86 & 41 \\
\hline Navruz & 4 & 6 & 88 & 34 & 38 & 41 & 87 & 46 \\
\hline Sevinch & 4 & 4 & 97 & 31 & 33 & 34 & 95 & 61 \\
\hline Samar $F_{1}$ & 4 & 4 & 97 & 31 & 33 & 34 & 97 & 63 \\
\hline Orzu F $F_{1}$ & 4 & 4 & 98 & 30 & 31 & 33 & 96 & 63 \\
\hline \multicolumn{9}{|c|}{ Trellis method } \\
\hline $\begin{array}{c}\text { Uzbekistan } \\
740 \\
\end{array}$ & 5 & 5 & 86 & 35 & 39 & 43 & 92 & 49 \\
\hline Navruz & 4 & 6 & 87 & 33 & 37 & 39 & 94 & 55 \\
\hline Sevinch & 4 & 4 & 97 & 29 & 31 & 31 & 102 & 71 \\
\hline Samar $F_{1}$ & 4 & 4 & 98 & 28 & 30 & 30 & 103 & 73 \\
\hline Orzu $F_{1}$ & 4 & 4 & 98 & 28 & 29 & 30 & 103 & 73 \\
\hline
\end{tabular}

The last harvest takes place within 86-97 days in a side shoots and the total length were higher. Among the usual way and for 92-103 days in the trellis way. This indicator determined the duration of yield in the experiment. At the same time, methods and seeding samples were compared. In the experiments, the duration of the yield on samples Orzu, Samar and Sevinch lasted a long time and lasted 71-73 days. This means that it is 10 days more than the usual method. The Navruz and Uzbekistan-740 varieties yielded a harvest of less than 49-55 days, which is 8-9 days more than in the conventional method.

The duration of the yield when growing cucumbers by the trellis method has grown due to the comfort of external factors and the efficiency by the trellis method.

In the experiment, biometric measurements were made. At the same time, growth and development of the above-ground upper part of plants was observed. In contrast to the conventional method, cucumbers grown by the trellis method had the most common differences in growth and development (table 2).

In the conventional method, the number of plants per hectare was 23809, the distance between the plants was 40 $\mathrm{cm}$ and therefore the height of the main stem, the number of samples of varieties, the length of the main stem was 122-168 $\mathrm{cm}$, the number of shoots - 2.6-6.5 and the number of leaves - 70.2-102.6.

When growing by the trellis method, the number of plants per hectare was 47619 and $30 \mathrm{~cm}$ distance between plants, the length of the main stem, the number of shoots and the total length were relatively low. Among the samples, the length of the main stem was from 120 to $156 \mathrm{~cm}$, the number of shoots was 2.0-4.3, and the number of leaves was 74,3-118,6. Experience shows that, compared with the usual method, the main stem length of the plant and smaller shoots were small in the trellis method, but the number of leaves was 2-14 more. These indicators depend on factors such as plant nutrition, absorption factors and exposure to the sun. Growing cucumber by the trellis method differs from the conventional method in sufficient light and a large number of assimilating surfaces. In both methods, it is shown that the varieties Uzbekistan 740 and Navruz have a relatively strongly growing above ground part. As a result of tying the main stems of the plant, and side shoots, it was easier to measure and care between the rows.

Table 2. Growth and development of the above-ground part of cucumber variety samples (2017-2018 yy).

\begin{tabular}{|c|c|c|}
\hline Variety samples & $\begin{array}{c}\text { Number of } \\
\text { plants per } \\
\text { hectare, pieces }\end{array}$ & $\begin{array}{c}\text { The length of } \\
\text { the main } \\
\text { stem, cm }\end{array}$ \\
\hline
\end{tabular}

The number of side shoots, pcs
The total length of the side shoots $\mathrm{cm}$
Number of eaves, pieces 


\begin{tabular}{|c|c|c|c|c|c|}
\hline \multicolumn{6}{|c|}{ The usual way } \\
\hline Uzbekistan 740 & 23809 & 168 & 6,2 & 575 & 92,3 \\
\hline Navruz & 23809 & 148 & 6,5 & 688 & 102,6 \\
\hline Sevinch & 23809 & 122 & 2,6 & 303 & 70,2 \\
\hline Samar $F_{1}$ & 23809 & 140 & 3,2 & 332 & 71,4 \\
\hline Orzu F $F_{1}$ & 23809 & 130 & 3,4 & 306 & 73,8 \\
\hline \multicolumn{6}{|c|}{ Trellis method } \\
\hline Uzbekistan 740 & 47619 & 156 & 4,3 & 396 & 106,3 \\
\hline Navruz & 47619 & 142 & 3,8 & 402 & 118,6 \\
\hline Sevinch & 47619 & 120 & 2,0 & 196 & 74,3 \\
\hline Samar F $F_{1}$ & 47619 & 131 & 2,2 & 210 & 76,4 \\
\hline Orzu F $F_{1}$ & 47619 & 125 & 2,4 & 244 & 79,0 \\
\hline
\end{tabular}

The experiment also carried out to observe the level of plant diseases. After 35 and 70 days after the emergence of cucumber seeds, observations were made. The most common diseases of cucumbers such as floury mildew and fusarium wilt were observed (visually) through observation.

As a result of the experiment, the spread of the disease by powdery mildew was $0.7-13 \%$ among the species in the usual way. In the case of cultivation by the trellis method 2 types, Navruz and Uzbekistan 740 were infected by $2.3 \%$ and $4.6 \%$, respectively. The remaining varieties are not infected. Fusarium wilt disease is common in the usual way among varieties of $5-15.2 \%$. In the case of a trellis method, the most affected varieties are Uzbekistan 740 and Navruz are subject to $6.0 \%$, and $4.8 \%$. The remaining varieties were infected with a low 0.2 and $0.8 \%$ disease. In the trellis method due to the good rotation of the wind and other factors there were less diseases.

Table 3. Productivity and quality indicators of varietal samples of an cucumber when growing in the usual and trellis way. (2017-2018 yy).

\begin{tabular}{|c|c|c|c|c|c|}
\hline Variety samples & $\begin{array}{l}\text { The average } \\
\text { weight of the } \\
\text { fruit, } g\end{array}$ & $\begin{array}{c}\text { Total } \\
\text { harvest, } \mathrm{t} / \mathrm{ha}\end{array}$ & $\begin{array}{c}\text { The share of } \\
\text { marketable } \\
\text { products, } \%\end{array}$ & $\begin{array}{l}\text { Marketable } \\
\text { yield, t/ha }\end{array}$ & $\begin{array}{l}\text { Calculation to the } \\
\text { usual method } \%\end{array}$ \\
\hline \multicolumn{6}{|c|}{ The usual way } \\
\hline Uzbekistan 740 & 155,4 & 23,5 & 86,5 & 20,3 & 100 \\
\hline Navruz & 143,4 & 30,9 & 88,6 & 27,4 & 100 \\
\hline Sevinch & 107,4 & 35,0 & 92,0 & 32,2 & 100 \\
\hline Samar F & 112,6 & 35,9 & 92,4 & 33,2 & 100 \\
\hline Orzu $F_{1}$ & 98,5 & 38,7 & 93,1 & 36,0 & 100 \\
\hline $\mathrm{LSD}_{05}$ & 9,6 & 1,7 & & 1.2 & \\
\hline $\mathrm{P}, \%$ & 2,2 & 3,8 & & 3,0 & \\
\hline \multicolumn{6}{|c|}{ Trellis method } \\
\hline Uzbekistan 740 & 150,2 & 27,8 & 88,5 & 24,6 & 121 \\
\hline Navruz & 131,8 & 35,4 & 91,4 & 32,4 & 118 \\
\hline Sevinch & 100,2 & 40,8 & 95,0 & 38,8 & 120 \\
\hline Samar F & 106,4 & 40,7 & 97,6 & 39,7 & 120 \\
\hline Orzu F & 95,3 & 43,6 & 98,2 & 42,8 & 119 \\
\hline $\mathrm{LSD}_{05}$ & 8,4 & 1,5 & & 1,1 & \\
\hline $\mathrm{P}, \%$ & 2.8 & 3,5 & & 3,8 & \\
\hline
\end{tabular}

The average weight of fruits in the usual method of production among varieties ranged from $98.5 \mathrm{~g}$ to $155.4 \mathrm{~g}$. In the trellis method it ranged from $95.3 \mathrm{~g}$ to $150.2 \mathrm{~g}$. results of both methods in terms of yield. When picking cucumber 23 times during the growing period, each crop is divided into separate fractions and weighed on a scale. As a result, the proportion of all fruits grown, commercial and average yield of commercial crops and the average weight of fruits were determined. Analyzing the varietal breed samples, it turned out that when growing in a trellis way, a higher yield is achieved. Compared with the usual method of cultivation by the trellis method, more varieties were received among the varieties: Uzbekistan-740 variety - 4.3, Navruz - 5.0, Sevinch - 6.6, in the Samar $F_{1}$ hybrid - 6.5 and Orzu $F_{1}-6,8 \mathrm{t} / \mathrm{ha}$. In addition, marketable products were: in the Uzbekistan-740 variety 24.6, in the Navruz variety - 32.4, in the Sevinch variety - 38.8, in the Samar $F_{1}$ hybrid - 39.7 and the Orzu $F_{1}$ hybrid -42.8 t/ha. In experimental samples, the highest rates of varieties were found in hybrids Sevinch,

Samar $F_{1}$ and Orzu $F_{1}$ (table 3).

Uzbekistan 740 varieties and a variety of Navruz were with relatively large fruits. The total yield in the usual way was 23.5-38.7 $\mathrm{t} / \mathrm{ha}$ and in the trellis 
method 27.8 to $43.6 \mathrm{t} / \mathrm{ha}$ at the same time. When calculating the share of total marketable yield, the trellis method was higher than the usual method. It was found that in Uzbekistan 740 the indicator is $88.5 \%$, i.e. $2 \%$ higher than normal. The result of a significant increase in the number of varieties was found: Orzu-98.2 (5.1\%), Navruz - 91.4\% (2.8\%), Samar $-97.6 \%$ (5.2\%), Sevinch - 95, 0\% (3.0). The proportion of yield varied from $98.2-97.6 \%$ to the highest in varieties of Orzu and Samar hybrids with a high level of productivity, high quality and difference from other varieties due to their productivity. With the lowest indicator, Uzbekistan 740 was $88.5 \%$, which was considered relatively unproductive, i.e. of fruits, with non-liquid form and other defects.

\section{CONCLUSIONS}

When growing early samples of cucumber production showed out that in all varieties of cucumber, cultivating by the trellis method gives $18-21 \%$ more production than with the usual method of planting. As a result of research varieties of hybrids Orzu, Samar and Sevinch varieties differed from other varieties with high performance, high quality and high marketability. We recommend to grow cucumbers on home gardens and not large open ground of small farms in a trellis way to receive fruits of high quality and high yield.

\section{REFERENCES}

1. Азимов Б.Ж., Азимов Б.Б. Сабзавотчилик, полизчилик ва картошкачиликда тажрибалар ўтказиш методикаси. Ўзбекистон миллий энциклопедияси. 2002. 224 бет.

2. Болотских А.С. Сорт - существенный элемент интенсивной технологии. // Материалы, доклады международного симпозиума «Современное состояние и перспективы развития селекции и семеноводства овощных культур». 9-12 августа 2005. М.РАСХН, 2005 г. Т-1. с 37-40.

3. Жученко А.А. Тенденции и приоритеты развития селекции в XXI веке. //Материалы междунар. научно-практ. конф. «Современные тенденции в развитии селекции и семеноводства овощных культур. Тенденции и перспективы» 4-8 августа 2008. М.ВНИССОК, 2008. T.1. с 10-37.

4. Gyula.A., Jozsef.L. Выращивание огурца на шпалерах (BHP). Реф. жур «Картофель овощные и бахчевие культуры» Москва-1986. №1. C. 15

5. Godnev L. Experiencing Cucumber Hybrids by Intensive Technology. J. "Gardening”№8. 2007. p. 16-17.

6. Деревенча М.Е. Опыт выращивания огурцов на шпалерах. Ж. «Картофель и овощи» 1988. № 2. с. 29-30.

7. Федоров А.В., Тутова Т.Н., Папонов А.Н. Выращивание огурца на подвоях. Ж.: Картофель и овощи. 2005. №7. с. 24-25.

8. Остонакулов Т.Э, Зуев В.И, Қодирхўжаев О.Қ. “Сабзавотчилик ” Тошкент - 2009. 312-321 бетлар.

9. Сидорова Э. Огурцы на опоре. Ж.”Сад и огород”. № 6. 2007. с.6

10. Тараканов Т.И. Мухин В.Д. Огурец Вкн: Овошеводство М: Колос 2003. с 379-398. 